\title{
The Scandinavian Scholar and America
}

\section{By Ward Miner}

\begin{abstract}
Prof. Ward Miner, Youngstown University, Ohio, (formerly visiting professor at Reykjavik University) gave a lecture at the Otnäs conference in which he discussed some of the most vital problems for researcbers in the Nordic countries upon the USA: \$Wat disadvantages has the foreign researcher in studying the USA and how can he avoid them? What are his advantages and how can he use them?,) The article below is a shortened version of prof. Miner's lecture.
\end{abstract}

Often as a visiting American in Scandinavia I have been asked something like this, 'What American subject can I work on when I'm so far away from the primary source material?» This question may well imply how having such scholarly interests will determine one's personal future. I realize, and I know my questioners realize it more vividly than I, the acute problems of academic prestige, of availability of academic positions. They do affect how much you may or can do in research about America. But the probleins of the robe of American Studies in the European academic scene I will here set aside and limit myself to the problem of what contributions can you as Scandinavians make to scholarship on America.

Easily I can state the difficulties you operate under, difficulties so many Europeans have reminded me of. The obvious one is the distance you are from America. Crossing the Atlantic takes not so much time as money. The expense may well effectively keep you from the manuscripts, the archives, the artifacts, the physical scene, the persons to be interviewed. For this reason the current interest in textual editing in America among historians both literary and political is so very important. Make sure your libraries, if at all 
possible, subscribe to such editions in progress as those of Jefferson, Franklin, Hamilton, Clay, Adams, and Twain. The elaborate techniques 'devised by Julian Boyd, for example, deserve close attention because the results he and other textual editors have achieved will be your and our basic research tools for years to come. You need to be able to evaluate your tools. Sometimes I become annoyed when I discover a typographical mistake for years eliminated but carefully restored by scrupulous scholar. But my quibbling in no way denies the usefulness of the editing chores. Also helpful to you separated as you are by the Atlantic Ocean from your interests is the technology of the past decade introduced by Xerox and similar firms. Photographic processes available to the scholar are both more accurate and less expensive than formerly. But just as William Manchester found pitfalls in a tape recorder, so you too are faced with the limitations as well as the conveniences of technical innovations.

However much I may have modified the geographical disadvantage you work under, I cannot pretend it does not exist. Same things can be done at the Truman Library in Independence, Missouri, that cannot be done at the USIS Library in Helsinki. But my second disadvantage is an intangible one and does not lend itself to palliation by gadgetry. You will more or less always be an outsider compared to the American, the insider. Since my contrasting terms are more metaphorical than precise, let me illustrate what I mean. My boyhood was spent in various rural and semi-rural communities in southeastern Iowa, where I grew up breathing in what I will call for want of a better term the Lincoln legend. I can remember my father's reading aloud to the assembled family a hero-worshipping book about Lincoln with some such title as The Man for the Ages. I am sure my adult mind would now regard the book as sentimental, but that's not really the important thing. I also remember well my father's describing the fascination he felt while verifying farm land titles in spotting the name of Lincoln as a practicing lawyer in various old court records in Oquawka, Illinois. I can baldly say that the Lincoln legend had a tremendous impact on my childhood, yes, but what does my bald statement mean to an outsider? Just as literary texture is not an easy concept to grasp, so is it difficult to put into words the textune of he boyhood with the Lincoln 
legend playing its role. I have deliberately used a literary concept because I happen to think that what I have called the texture of life is important, and literature can present this elusive quality best. The texture and the data or the facts of something may well not be the same thing, making for difficulties in putting them together. As scholars living where you do, you therefore have a special obligaoion to saturate yourself in the literature of America to comprehend better its history.

Already I have spent too long on qualifying the disadvantages you have, because I am much more concerned about the advantages you have just because you are not Americans nor are you in America. If there are those of you who feel timid or insecure about studying some aspect of America, I would like to encourage a pride in you for being the Scandinavian scholar on America, a pride based on an awareness that you can make certain contributions better than anybody else. Instilling this pride in you is made easier by the existence of a Scandinavian tradition of scholarship extending from Peter Kalm to Lars Ahnebrink, both men interestingly enough from the same university.

The first advantage I want to call to your attention is perspective, a perspective gained because you are on this side of the Atlantic Ocean. As an American studying America, I find myself so often saying, »How can I detach myself from my own oultural milieu?» and realizing that frequently I won't be able to. The acquiring of perspective is one of the most important reasons for an American's teaching American material outside his home country. So often we defend the work of Fulbnight professors in Europe as a contribution to the European academic scene. Perhaps we should be stressing the contribution these professors make on their return to the American academic scene. But a perfect example of the perspective you have about America is Gunnar Myrdal and the writing of An American Dilemma. The excellence of those two volumes says more about the valute of perspective than I can put into words.

A second advantage is an ability to make comparisons. This can be overdone, of course, but my point is that overdoing it is more of a trap for Americans than it is for you. Knowing the history, the literature of your own country can help make you a better 
scholar on America. I suppose emphasizing this results from hours spent in a classroom trying to imagine comparisons so that students can better understand something. For example, I have always found the following comparison useful in my own thinking as well as in the classroom. Several critics, enough that it is difficult to pin down who said if first, have pointed out how American and Russian literatures share a similar attitude towards space, an attitude much less often present in any of the literatures of Western Europe. Like all good analogies this has the value of suggestiveness rather than definitiveness, and that is as it should be. The comparisons you can make will also illumine what is blurred for the American.

A third advantage I see is a freedom you possess, a freedom from the prejudices and the preconceptions any person has about himself, his family, his native soil. Because you are human beings, you have prejudices of your own, but what is useful to you as scholars is that they are usually not the American ones. The virtues of being an outsider outweigh whatever gains the insider might think he has. In the future somebody will have the task of writing a history of the cold war between United States and Russia. If one of you sitting here ever feels so inclined, you will have advantage over any American or any Russian.

Until now I have, by means of comparisons, been looking at the advantages and disadvantages a Scandinavian scholar has in American Studies. Suppose I move on to ask what can this Scandinavian scholar emphasize and accomplish that will be not only effective but meaningful?

My first answer needs emphasis and repetition. If you become interested in a problem, go to it. Forget all about hypothetical advantages, disadvantages, or what-have-you. There's no greater satisfaction than having delved well into something you and perhaps nobody else wanted to dig into. Personal taste and curiosity are fundamental. Pick your own subjects for study. If I seem to belabor the obvious, good. Then I need not elaborate.

I am now going to express a perhaps paradoxical hope about the results you as scholars on American will obtain. I hope you will study and uncover American failures, weaknesses. Why do I emphasize this for you as Scandinavians? One reason is that you can contnibute something very important to America. Because you 
have the advantages already described, you may well recognize something as a failure that Americans cannot or will not.

To make concrete my abstraction. You have all heard some variant of a question asked by touristiug Americans: Why are Scandinavians sexually promiscuoas? I need not tell this audience how silly the question is. In fact, I deliberately chose a question you would react to as boring, even a bit annoying. Trying to answer the American tourist's question gets nowliere, hence your disgust. But suppose you turn the trite question around and ask why do Americans find it necessary to ask such a question? Is there a weakness in American attitudes that impels sucli questions? Because you can adopt the point of view which says your own life is a norm and the American a deviant, you could follow this guestion by - why and how did Americans develop liypocrisy about sex? Why has prudery played such an important role in American history? Now we've moved from tlie ridiculous to perhaps not the sumblime, but at least to something penetrating. The history of American prudery has never been written because the subjoct needs. I suspect, the skeptical mind of a Scandinavian. The ramifications of the subject - and that is why I call it »penetrating» lead the investigator into such aspects of America as literary censorship both explicit and implicit, immigration (labelling actions or attitudes of immigrants as obscene may well be a means of trying to exclude the newcomers from American life), the frontier (I include this because I suspect that one of the results of the second generation of the frontier when the drive towards respectability replaces the drive West is prudery), Victorianism (which brings in cultural relations with England), and puritanism (which in this connection may well. turn out to be Victorianism under a masquerade).

Frequently in the States I have listened to discussions and read articles on why has America changed from a 17th century religiousoriented society to a $2 \mathrm{Q}$ ah century secular variety. Every time I am in any of tlie five Scandinavian countries I a m always reminded that the much more revealing question is - why have Americans throughout their history been so religious-minded? Dc 'Tocqueville as early as the 1830 s commented on this aspect of American life, and so have other foreign observers. Answers to this are not going 
to be easy, involving as it does attitudes towards and by immigrant groups. I include the »by» because I would very much like to understand why do immigrants to the States tend so often, though not always, to cling to values one generation back from their own. Your knowledge of the sociocultural histories of your own contries is needed here.

My two examples suggest how your vantage point can help us comprehend America. Now I want to turn this around and examine how your studying our failunes and weaknesses is relevant to the Scandinavian countries themselves. In our capacity as historians we talk about how we can learn from the past, including the mistakes of the past. That England went through its Industrial Revolution the first half of the 19th century made it that much easier for America and the countries of Western Europe as they went through a similar historical process the latter half of the same century. In hindsight, a more careful study of England's difficulties during industrialization could have at least alleviated if not prevented the repetition of many a tribulation. That Marx and Engels made their conclusions as a result of observation of these difficulties only increases the poignancy of the failure of other studies.

To exemplify how you might profit from our failures, let me use that conspicuous problem of the Negro in America. I realize you have few Negroes in Scandinavia, nor do you really have what the sociologist would call ethnic minority groups. Bun; suppose instead of talking about Negro-white or ethnic minority groups I use the bland terms of the sociologist and speak of a people pushed too quickly from a rural, peasant-like if you will, society into an urban, industrialized way of life. Those of you who know the States can give American Negro equivalents of these anecdotes told about peasants in Yugoslavia trying and failing to make the shift from rural to urban life. $\gg$ One family housed a cow in its second-story apartment in Sarajevo. Two goats dwelt on the thirteenth story of a Belgrade apartment house. The family kept them in the bathroom and milked them regularly. They even chopped up the tile floor so that the animals would not find it so slippery underfoot.» The American writer from whose book I have been quoting later says, »I often heard old resident of 
Belgrade talk about the slovenliness of new families in from the country in the way that proper middle-class people used to talk in America about southern Negroes or West Virginia coal miners»1 For complex reasons America has been unsuccessful. with so many people as they move from rural peasantry to urban proletariat, from West Virginia coal mine to Youngstown steel mill, from Russian village to New York ghetto. I remember an incident from my own boyhood in a semirural community in the Midwest. A Scandinavian family moved from a farm into the town where I lived, bringing with them goats. Enougli of a tempest in a teapot resulted that eventually the town council banned all goats from within the town limits. Why did the farmers not recognize the obnoxious smell of goats and their unsanitary habits as the rest of us presumably did? So often I heard, $\gg$ After all, what else can you expect? They're only Scandihoovians». I wonder, how many incidents can you tell which end with - they're only Lapps, or Italians, or dumb farmers from this or that province? In other words, you can, if you will, learn much from our failures with the American Negro about what happens as values become obliterated in the process of urbanization and industrialization. I wish I could offer you solutions instead of problems, but this is where your scholarship can take over.

However, taking advantage of our weaknesses need not mean an obsession with them. We do observe without making moral judgments. Perhaps as observers remote from the American scene you may be able to show us participants chat the moral judgments we make about ourselves are actually only the elongated shadows of our prejudices. This is another way of saying my final point. Whether you interpret your observations as failure or success, don't hesitate to make the judgement. Be the interpreter more than the recordar of the American scene. Of course, you may well be criticized for your interpretations, especially by Americans. That Americans yelped in protest when Dickens in 1842 published his American Notes in no way invalidates the acuteness of his comments. Because you are scholars with a respect for the observable, the verifiable, I have no worry of your contenting yourself with

1 David Tornquist, Look East Look West: The Socialist Adventure in Yugoslavia (New York: Macmillan, 1960), pp. 52, 54. 